\title{
Penerapan Model Pembelajaran Role Playing dengan Media Audio Visual untuk Meningkatkan Pembelajaran IPS tentang Kegiatan Jual Beli pada Siswa Kelas III SDN 2 Tanahsari Tahun Ajaran 2018/2019
}

\author{
Rizki Aulia1, Ngatman², Ratna Hidayah ${ }^{3}$ \\ 1,2,3 Universitas Sebelas Maret \\ rizkiaulia668@gmail.com
}

\section{Article History}

accepted 01/10/2019

approved 01/11/2019

published 01/12/2019

\begin{abstract}
The purpose of this study is to describe the application of role playing models with audio-visual media, improve social studies learning through role playing models with audio-visual media, and describe the obstacles and solutions to the application of role playing models to audio-visual media. This classroom action research is a collaborative research carried out in three cycles with the stages of planning, implementation, observation, and reflection. The subject of this study was third grade students of SD N 2 Tanahsari. The results of the study show that the application of the role playing model with audio visual media can improve social studies learning outcomes. Constraints that arise in the application of the role playing model with audio-visual media are students who have not animated the role characters that are played well. The solution given by researchers is that students are given motivation by the teacher to be brave in expressing, brave, and more confident when playing drama.
\end{abstract}

Keywords: role playing, audio visual, IPS learning

\begin{abstract}
Abstrak
Tujuan penelitian ini adalah untuk untuk mendeskripsikan penerapan model role playing dengan media audio visual, meningkatkan pembelajaran IPS melalui model role playing dengan media audio visual, dan mendeskripsikan kendala dan solusi penerapan model role playing dengan media audio visual. Penelitian tindakan kelas ini merupakan penelitian kolaboratif yang dilaksanakan dalam tiga siklus dengan tahap perencanaan, pelaksanaan, pengamatan, dan refleksi. Subjek penelitian ini adalah siswa kelas III SD N 2 Tanahsari. Hasil penelitian menunjukkan penerapan model role playing dengan media audio visual dapat meningkatkan hasil belajar IPS. Kendala yang muncul dalam penerapan model role playing dengan media audio visual yaitu siswa belum menjiwai karakter peran yang dimainkan dengan baik. Adapun solusi yang diberikan peneliti yaitu siswa diberikan motivasi oleh guru agar berani berekspresi, berani, dan lebih percaya diri saat memainkan drama.
\end{abstract}

Kata kunci: role playing, audio visual, pembelajaran IPS 


\section{PENDAHULUAN}

Berdasarkan UU RI No 20 tahun 2003 pasal 1 bahwa pendidikan adalah usaha sadar terencana untuk mewujudkan suasana belajar dan proses pembelajaran agar peserta didik aktif mengembangkan potensi dirinya untuk memiliki kekuatan spiritual keagamaan, pengendalian diri, kepribadian, kecerdasan, akhlak mulia, serta keterampilan yang diperlukan dirinya, masyarakat, bangsa dan negara. Tujuan pendidikan nasional salah satunya dapat diwujudkan melalui mata pelajaran IImu Pengetahuan Sosial (IPS).

IPS merupakan gabungan dari berbagai cabang ilmu sosial dan humaniora, meliputi sosiologi, geografi, hukum, politik, ekonomi, budaya, dan sejarah (Susanto, 2014: 8). Berdasarkan Permendiknas Nomor 22 Tahun 2006, tujuan pembelajaran IPS di tingkat Sekolah Dasar adalah sebagai berikut: (1) mengenal konsep-konsep yang berkaitan dengan kehidupan masyarakat dan lingkungannya; (2) memiliki kemampuan dasar untuk berpikir logis dan kritis, rasa ingin tahu, inkuiri, memecahkan masalah, dan keterampilan dalam kehidupan sosial; (3) memiliki komitmen dan kesadaran terhadap nilai-nilai sosial dan kemanusiaan; (4) memiliki kemampuan berkomunikasi, bekerja sama dan berkompetisi dalam masyarakat yang majemuk, di tingkat lokal, nasional, dan global.s

Berdasarkan hasil wawancara dan observasi yang dilakukan pada tanggal 12 November 2018, pada saat pembelajaran di kelas guru menerangkan materi pembelajaran dengan metode ceramah, tanya jawab dan diskusi. Dalam pembelajaran, guru sudah melibatkan siswa namun, terlihat hanya beberapa siswa yang aktif. Pembelajaran yang dilaksanakan sudah baik, namun belum secara maksimal.

Peneliti juga melakukan wawancara kepada guru kelas III SD Negeri 2 Tanahsari. Menurut guru kelas III SD Negeri 2 Tanahsari, materi IPS kelas III cukup banyak, sehingga pada saat pembelajaran siswa merasa bosan, kurang semangat, dan kurang tertarik pada saat pembelajaran.

Berdasarkan data nilai Ulangan Tengah Semester (UTS) diketahui bahwa nilai UTS mata pelajaran IPS dari 20 siswa, terdapat 11 siswa yang nilainya melebihi KKM dan 9 siswa yang belum mencapai KKM dengan KKM 75. Hal ini menunjukkan bahwa hasil belajar IPS pada siswa kelas III SD Negeri 2 Tanahsari masih tergolong rendah. Berdasarkan kondisi pembelajaran yang terjadi di kelas III SD Negeri 2 Tanahsari diperlukan adanya perbaikan pembelajaran untuk menangani permasalahan tersebut. Salah satunya yaitu dengan penerapan model pembelajaran yang inovatif dan menyenangkan.

Salah satu model pembelajaran yang peneliti terapkan yaitu model pembelajaran role playing karena model ini merupakan suatu model pembelajaran dengan cara siswa berperan atau memainkan peranan dalam dramatisasi sebuah masalah. Roestiyah (2012: 93) mengemukakan kelebihan role playing yaitu menarik minat siswa dalam belajar, mempermudah siswa dalam memahami materi, menumbuhkan sikap saling pengertian terhadap sesama makhluk, serta dapat mengaktifkan peserta didik dalam kegiatan pembelajaran. Model role playing akan lebih maksimal hasilnya apabila didukung dengan suatu media. Langkah-langkah role playing yang dikemukakan oleh Shoimin (2014: 162) yaitu: (a) guru menyusun/menyiapkan skenario yang akan ditampilkan, (b) menunjuk beberapa siswa untuk mempelajari skenario dua hari sebelum KBM, (c) membentuk kelompok siswa yang anggotanya 5 orang, (d) memberikan penjelasan tentang kompetensi yang ingin dicapai, (e) memanggil para siswa yang sudah ditunjuk untuk melakonkan skenario yang sudah diipersiapkan, (f) masing-masing siswa duduk dikelompoknya, sambil memperhatikan skenario yang sedang diperagakan, (g) setelah dipentaskan, masing-masing siswa diberikan kertas 
sebagai lembar kerja untuk membahas, (h) masing-masing kelompok menyampaikan hasil kesimpulannya, (i) guru memberikan kesimpulan secara umum, (j) evaluasi, (k) penutup.

Salah satu media pembelajaran yang digunakan dalam pembelajaran IPS yaitu media audio visual. Media audio visual ini cocok diterapkan dalam pembelajaran IPS karena dapat meningkatkan motivasi siswa saat mengikuti pembelajaran. Dengan meningkatnya motivasi belajar siswa, maka hasil belajar siswa akan meningkat. Media audio visual sebagai media penyaluran pesan dengan memanfaatkan indera pendengaran dan penglihatan. Secara umum, media audio visual menurut teori kerucut pengalaman Edger Dale memiliki efektifitas yang tinggi daripada media audio atau visual (Sukiman, 2012: 184).

Maka dari itu, penerapan model role playing dengan media audio visual diharapkan dapat meningkatkan dan hasil belajar IPS pada siswa kelas III SDN 2 Tanahsari.

Berdasarkan uraian di atas, dapat dirumuskan masalah sebagai berikut: (1) bagaimanakah penerapan model role playing dengan media audio visual untuk meningkatkan pembelajaran IPS pada siswa kelas III SD N 2 Tanahsari Tahun Ajaran 2018/2019?; (2) apakah penerapan model role playing dengan media audio visual dapat meningkatkan pembelajaran IPS pada siswa kelas III SD N 2 Tanahsari Tahun Ajaran 2018/2019?; (3) apa kendala dan solusi penerapan model role playing dengan media audio visual untuk meningkatkan pembelajaran IPS pada siswa kelas III SD N 2 Tanahsari Tahun Ajaran 2018/2019?.

Tujuan penelitian ini, yaitu: (1) mendeskripsikan penerapan model role playing dengan media audio visual untuk meningkatkan pembelajaran IPS pada siswa kelas III SD N 2 Tanahsari Tahun Ajaran 2018/2019; (2) meningkatkan pembelajaran IPS melalui model role playing dengan media audio visual pada siswa kelas kelas III SD N 2 Tanahsari Tahun Ajaran 2018/2019; (3) mendeskripsikan kendala dan solusi penerapan model role playing dengan media audio visual untuk meningkatkan pembelajaran IPS pada siswa kelas III SD N 2 Tanahsari Tahun Ajaran 2018/2019.

\section{METODE}

Penelitian ini akan dilaksanakan mulai bulan Oktober 2018 sampai Mei 2019. Subjek penelitian ini adalah guru kelas III dan siswa kelas III SD N 2 Tanahsari Tahun Ajaran 2018/2019. Jumlah siswa kelas III adalah 20 siswa yang terdiri dari 9 siswi perempuan dan 11 siswa laki-laki yang memiliki kemampuan dan latar belakang yang berbeda-beda.

Data yang digunakan pada penelitian tindakan kelas ini berupa data kuantitatif dan data kualitatif. Data kualitatif yaitu penerapan model role playing dengan.media audio visual, data wawancara dan hasil observer, sedangkan data kuantitatif yaitu hasil belajar IPS siswa. Menurut Miles dan Huberman (Sugiyono, 2015: 337-345), alur menganalisis data terbagi tiga, yaitu: reduksi data, penyajian data, dan penarikan kesimpulan.

Pada penelitian ini, peneliti menggunakan triangulasi teknik (hasil tes, observasi, dan pedoman wawancara) dan triangulasi sumber data (guru dan siswa kelas III SD N 2 Tanahsari). Pada penelitian ini, teknik analisis data yang digunakan yaitu analisis data kualitatif untuk menganalisis penerapan model role playing dengan media audio visual dalam pembelajaran IPS tentang kegiatan jual beli dan data kuantitatif untuk menganalisis hasil berupa hasil belajar siswa.

Teknik analisis data yang digunakan yaitu analisis data kualitatif untuk menganalisis penerapan model role playing dengan media audio visual dalam pembelajaran IPS tentang kegiatan jual beli dan data kuantitatif untuk menganalisis hasil berupa hasil belajar siswa. 
Indikator kinerja penelitian yang ditargetkan dalam penelitian ini yaitu $85 \%$ untuk aspek penerapan langkah-langkah model role playing dengan media audio visual, keaktifan dan kerja sama siswa dalam pembelajaran IPS melalui penerapan role playing dengan media audio visual, dan emampuan belajar siswa dalam pembelajaran IPS melalui penerapan role playing dengan media audio visual.

\section{HASIL DAN PEMBAHASAN}

Penerapan pembelajaran dengan menerapkan model pembelajaran role playing dilaksanakan selama tiga siklus, siklus I terdiri dari 2 pertemuan, siklus II terdiri dari 2 pertemuan, dan siklus III terdiri dari 1 pertemuan.

Proses pembelajaran IPS melalui penerapan model role playing de-ngan media audio visual dilaksana-kan dalam sembilan langkah yaitu (a) menetapkan topik atau masalah serta tujuan yang hendak dicapai melalui penayangan video, (b) memberikan gambaran masalah dalam situasi yang akan diperankan, (c) menetapkan pemain yang akan berperan, (d) memberikan kesempatan kepada siswa untuk bertanya, (e) mengamati dan membimbing bermain peran, (f) mengevaluasi peran, materi, dan drama yang dimainkan, (g) melakukan diskusi tentang drama atau materi yang disimulasikan, (h) merumuskan kesimpulan, (i) evaluasi. Langkah model role playing dengan media audio visual tersebut, sesuai dengan pendapat Sanjaya (2006:161) dan Shoimin (2015: 161).

Hasil belajar siswa kelas III mengalami peningkatan pada tiap siklusnya. Hal ini terbukti dengan adanya perbandingan sebagai berikut.

Tabel.1 Perbandingan Hasil Belajar Siswa pada Siklus I, II, dan III

\begin{tabular}{llll}
\hline & Siklus & $\begin{array}{l}\text { Siklus } \\
\text { I }\end{array}$ & $\begin{array}{l}\text { Siklus } \\
\text { III }\end{array}$ \\
\hline Tuntas & 67,5 & 77,5 & 90 \\
Belum & 32,5 & 22,5 & 10 \\
Tuntas & & \\
\hline
\end{tabular}

Berdasarkan tabel 4.1 di atas, dapat diketahui bahwa persentase ketuntasan hasil belajar meningkat dari siklus I sampai siklus III. Persentase ketuntasan hasil belajar meningkat sebesar $10 \%$ dari siklus I ke siklus II. Peningkatan persentase dari siklus II ke siklus III sebesar 12,5\%. Berdasarkan data tersebut maka dapat disimpulkan bahwa terjadi peningkatan pada setiap siklus dalam melaksanakan model role playing dengan media audio visual.

Hasil penelitian tersebut sejalan dengan penelitian yang dilakukan oleh Nafisah (2016) yang berjudul "Penerapan Model Role playing Dengan Media Audio visual untuk Meningkatkan Motivasi Dan Hasil Belajar IPS Pada Siswa Kelas V SDN 1 Brecong Tahun Ajaran 2015/2016". Penelitian ini menghasilkan kesimpulan bahwa penggunaan metode role playing dengan media audio visual dapat meningkatkan motivasi dan hasil belajar siswa.

Semua langkah model role playing, dapat membuat siswa untuk lebih aktif dan semangat saat mengikuti pembelajaran. Dengan berperan aktifnya siswa saat pembelajaran, maka dapat membuat siswa lebih mudah memahami materi pembelajaran yang dipelajari. Hal ini terbukti karena hasil belajar siswa meningkat pada tiap siklusnya.

Kendala yang muncul dalam penerapan model role playing dengan media audio visual yaitu siswa belum menjiwai karakter peran yang dimainkan dengan baik. Adapun solusi yang diberikan peneliti yaitu siswa diberikan motivasi oleh guru agar berani berekspresi, berani, dan lebih percaya diri saat memainkan drama.

Menurut Shoimin (2014: 162-163) kelebihan role playing yaitu: sangat menarik bagi siswa dan kelas menjadi dinamis dan penuh antusias dan berkesan kuat dalam 
ingatan siswa, sehingga siswa dapat memahami materi dengan baik melalui role playing ini. Selain model role playing, media audio visual juga dapat meningkatkan hasil belajar siswa. Menurut Hamdani (2011: 249) media audio visual dapat menyajikan bahan ajar kepada siswa semakin lengkap dan optimal. Selain itu, juga dapat menggantikan peran dan tugas guru. Melalui penayangan video tersebut, siswa dapat memahami tujuan pembelajaran apa yang akan mereka pelajari.

\section{SIMPULAN}

Berdasarkan hasil penelitian, dapat disimpulkan bahwa (1) pene-rapan model role playing dengan media audio visual dapat mening-katkan hasil belajar siswa kelas III SDN 2 Tanahsari tahun ajaran 2018/2019, (2) kendala dan solusi dalam menerapkan model role playing dengan media audio visual. terdapat beberapa kendala yaitu (a) siswa belum menjiwai karakter peran yang dimainkan dengan baik. Adapun dari kendala tersebut yaitu (a) siswa diberikan motivasi oleh guru agar berani berekspresi, berani, dan lebih percaya diri saat memainkan drama.

\section{DAFTAR PUSTAKA}

Badan Standar Nasional Pendidikan (BSNP, 2006: 583)

Hamdani. (2011). Strategi Belajar Mengajar. Bandung: Pustaka Setia.

Nafisah, L.A. (2016). Penerapan Model Role playing Dengan Media Audio visual Untuk Meningkatkan Motivasi Dan Hasil Belajar Ips Pada Siswa Kelas V Sdn 1 Brecong Tahun Ajaran 2015/2016. Skripsi Tidak Dipublikasikan. Universitas Sebelas Maret, Surakarta.

Roestiyah, N.K. (2012). Strategi Belajar Mengajar. Jakarta: Rineka Cipta.

Shoimin, A. (2014). 68 Model Pembelajaran Inovatif dalam Kurikulum 2013. Yogyakarta: Ar-Ruzz Media.

Sugiyono. (2015). Metode Penelitian Pendidikan. Bandung: Alfabeta.

Susanto, A. (2016). Teori Belajar dan Pembelajaran di Sekolah Dasar. Jakarta: Prenada Media Grup. 